軽金属 第71巻 第8号 (2021), 400-405 DOI: 10.2464/jilm.71.400

(c) 2021 The Japan Institute of Light Metals

\title{
爆発圧着による各種軽金属合金と異種金属材料の接合
}

\section{Explosive welding of dissimilar metals for various light metals}

\author{
外本 和幸 \\ Kazuyuki HOKAMOTO
}

\section{1. はじめに}

現在,「マルチマテリアル化」という用語が流行しており， 異材の接合は接合研究者にとっても重要な課題となってい る。爆発圧着法は金属の異材接合法として工業的利用技術が 確立されており，広範な利用がなされている。特に金属同士 の異材接合に関しては，接合強度に優位性があることが知ら れている ${ }^{1)-5)}$ 。本稿は「軽金属」誌での講座なので, 内容を 各種の軽金属の異材接合を中心として, 生じている現象・接 合メカニズムや接合性の改善手法, 工業的応用例を紹介する ことに加えて, 関連する各種の高速材料加工技術の動向も含 めて研究の現状について解説する。

\section{2. 爆発圧着法の概要と関連技術の紹介}

爆発圧着の方法については多くの解説記事 ${ }^{1)-5)}$ があるが, 基本的には数百 $\mathrm{m} / \mathrm{s}$ の高速度で 2 枚の金属板が傾斜衝突をす ることで両材料を強固に接合する技術である。接合に寄与す るのは衝突点前方に生じる高速流れ（金属ジェット）であり， 材料表面の酸化物や污染を排除した後，新生面同士が高圧で 圧接されることによって良好な接合が得られる。溶接分野に おける位置付けとしては, 熱影響が少ない冷間圧接に分類さ れるものの, 微視的にみると, 接合境界の近傍では液相から の超急冷に起因して生じるアモルファスや準結晶組織がみら れたりする (6)-9)。金属ジェットの多くは衝突点前方に排出さ
れるものの，材料表面のごく薄い部分が高温にさらされるこ とで両金属の接合に寄与していると思われる。

一般に爆轟ガスの瞬時の広がりによって, 金属ジェットの 光学観察は難しい。図 1 は, 火薬銃を用いて爆発圧着が達成 可能な数百 $\mathrm{m} / \mathrm{s}$ の速度に加速した $40 \mathrm{~mm}$ 径の金属板を, 15〜 $20^{\circ}$ の角度で高速加速・衝突させて高速度ビデオカメラで連 続撮影した結果を示す ${ }^{10)}$ 。金属ジェットの状態については多 くの議論はあるが，衝突点前方に別の金属ブロックを置いて 金属ジェットをトラップした実験によると, 数百 $\mu \mathrm{m}$ 以下の 微細な粒子になって分散しているようである ${ }^{11) 。 ~}$

爆発圧着した接合界面は, 後述のように規則的な波状組織 を呈することが多い。爆発圧着時の衝突圧力は, おおむね数 〜数十 $\mathrm{GPa}$ と見込まれる。このような高い圧力下の材料は塑 性流動状態にあると考えられ, 高速下で流体力学的な不安定 現象を生じて波が形成されると説明されている ${ }^{12)}$ 。最近では 数值シミュレーションによって, 波の形状予測が多く行われ ている ${ }^{13)-15)}$ 。波の形成を良好な接合の指標とみなす場合も 多いが，平滑な境界でも接合条件が良好であれば高い接合強 度を示す場合もあるので注意が必要である ${ }^{16)}$ 。特に接合する 材料間で密度や強度 (硬度) が異なる場合には, 平滑な接合 界面を示す場合が多い ${ }^{16)}$ 。

接合可能な条件に関しては, 水平方向への衝突点移動速度 と接合時の衝突角が重要な因子であり,このことに基づいた Welding Window が提案されている ${ }^{17), 18)}$ 。接合可能な条件範

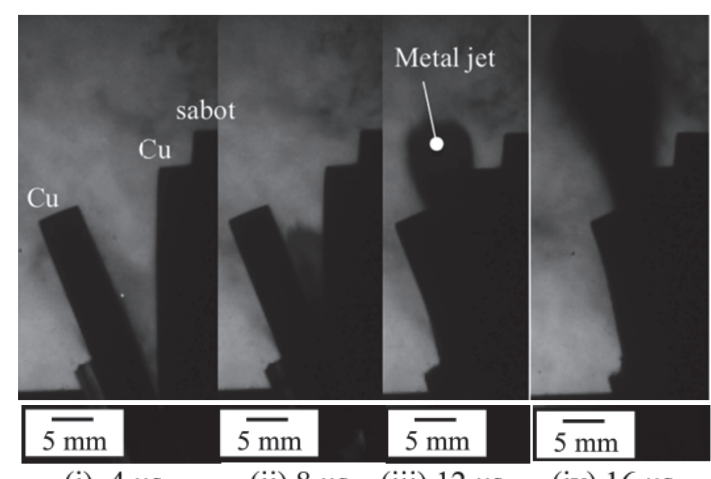

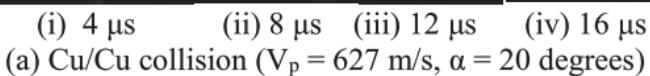

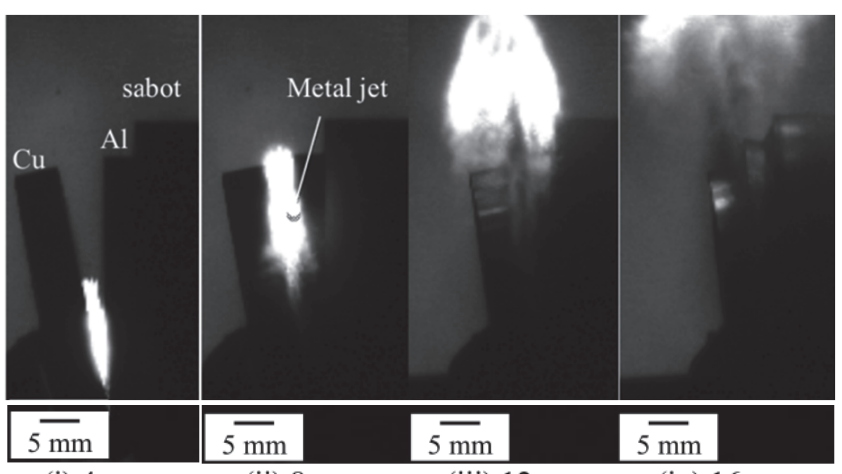

(i) $4 \mu \mathrm{s}$ (iii) $12 \mu \mathrm{s}$

(iv) $16 \mu \mathrm{s}$

(b) $\mathrm{Al} / \mathrm{Cu}$ collision $\left(\mathrm{V}_{\mathrm{p}}=464 \mathrm{~m} / \mathrm{s}, \alpha=15\right.$ degrees)

図1 火薬銃を用いた銅板同士およびアルミ・銅の傾斜衝突による金属ジェットの発生状況の光学観察結果 ${ }^{10)}$

熊本大学産業ナノマテリアル研究所 ( † 860-8555 熊本県熊本市中央区黒髮2-39-1) Institute of Industrial Nanomaterials, Kumamoto University (239-1 Kurokami, Chuo-ku, Kumamoto-shi, Kumamoto 860-8555)

責任著者E-mail：hokamoto@mech.kumamoto-u.ac.jp

受付日：2021年1月30日受理日：2021年3月 16 日 


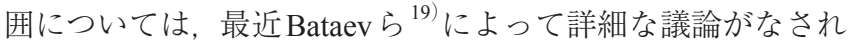
ているので, ここでは割愛する。

良好な接合を得るためには，いずれにしても衝突点におけ るエネルギーの制御が必要であり, 特に難接合の材料組合せ の場合, 接合しようとする材料の組合せごとに実験条件の適 正值を調整する必要がある。特にエネルギー過剩で接合境界 に溶融や化合物を厚く形成する場合に接合不良が生じること から, 衝突点 (接合境界) がエネルギー過剩な状態にならな いようにすることが肝要である。

\section{3. 各種軽金属の接合事例}

\section{1 中間材を用いる爆発圧着法}

通常の爆発圧着法の模式図を図 2 (a) に示す。通常法を用 いる場合，前述したようにエネルギー過剩で接合不良を生じ る場合が時折生じる。著者は以前, アルミニウムとステンレ ス鋼の接合に際して図2(b) のようなステンレス鋼の中間材 を挿入した接合法を提案してアルミニウム/ステンレス鋼境 界のエネルギー低減効果の有効性を明らかにした ${ }^{16)}$ ほか, 最 近ではアルミニウム/2相ステンレス鋼の接合にも成果を挙げ ている ${ }^{20)}$ 。同様の方法は他の材料の組合せにも応用が可能な ので, ここではチタン（TP340）とステンレス鋼（SUS304） に関する接合事例を紹介する ${ }^{21)}$ 。

中間材を用いる方法で得られた接合境界組織の一例を図3 に示す ${ }^{21)}$ 。図3の（a，（b）は光学顕微鏡組織，(c) は接合 境界のSEM像，（d），（e）はチタンと鉄の元素マッピング像 である。チタンとステンレス鋼の接合境界はわずかに波打っ ている程度で，接合境界に化合物の形成はあまり認められな

(a)

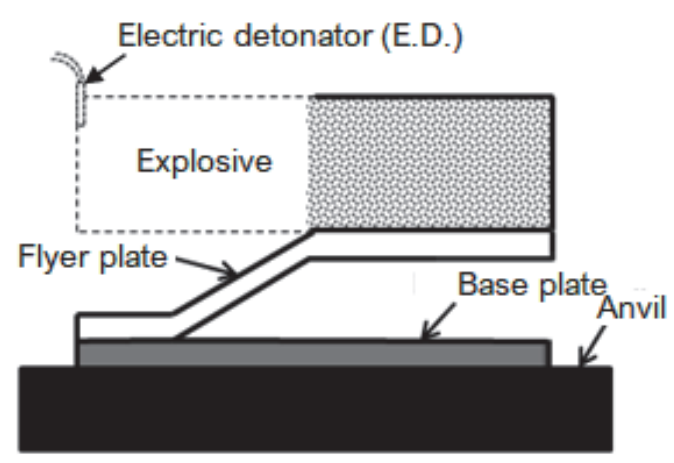

(b)

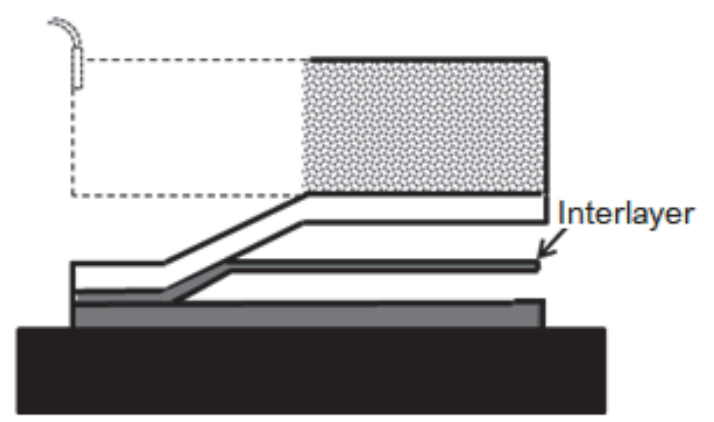

図2 爆発圧着法の模式図（a）通常法，（b）中間材を 用いる方法
いことから，エネルギーの低減効果は明らかであった。また， ステンレス鋼同士は規則的で大きな波を形成して, 良好に接 合されていた。

中間材を用いる場合であっても, 条件によってはエネル ギー過剩で化合物を多少形成するような場合も生じる。そこ で，エネルギーを抑制した試験片とエネルギー過剩で化合物 を形成している試験片に対して，もう1枚チタン板を別途爆 発圧着すること（動的試験）を行った時の接合境界組織を図 4に示す。図4(a) に示すエネルギーを抑制して化合物が無い 場合には良好な接合が維持される。図 $4(\mathrm{a})$ の矢印は, 中間 材と母材の境界を示す。一方, 図4(b) のようにエネルギー 過剰で化合物が存在する場合には化合物を起点とした割れ (図中矢印) が生じることが知られた ${ }^{21)} 。$

\section{2 水中衝撃波を用いる方法}

アルミニウムとマグネシウムの爆発圧着に関しては, 純ア ルミニウムとマグネシウム合金 (AZ31) の接合は通常法を用 いた場合でも，比較的容易であった ${ }^{22)}$ 。しかしながら，それ 以外のアルミニウム合金とマグネシウム合金の爆発圧着は, マグネシウムの低い融点と反応性に加えて, 延性が低く容易 にせん断帯を形成するようなことも生じやすく, 良好な接合 を得るにはさらに工法の工夫が必要であった。

そのために独自に開発した装置の模式図を図5に示す ${ }^{23)}$ 。 罒に示すように, 本実験では装置全体を水中に設置し, 爆薬 を傾斜させて行う水中衝撃波を利用する方法を使用した。こ の時使用した爆薬 (SEP) は, 爆轟速度が $7 \mathrm{~km} / \mathrm{s}$ 程度と比較 的高爆速で強力な爆薬であり, 傾斜させて水平方向への衝突

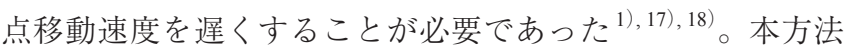
は, 媒質（水）を介することによって，薄板材料を均一に高 速加速できるとともに，回収された材料の表面も元の材料の 表面形状を維持してほとんど変化しないのが特徴である。薄 板の高速加速が可能であれば，運動エネルギーそのものを低 減することが可能で, 接合条件の改善に大きく寄与すること が期待される。

ここでは，水中衝撃波を利用する方法を用いて実施したチ タン（TP270）とマグネシウム合金（AZ31）の実験結果につ いて紹介する ${ }^{23)}$ 。ここで, チタンとマグネシウム合金の接合 は水中衝撃波を用いる方法だけでは実現が困難であったの で，前述と同様に母材と同じ材質の $0.3 \mathrm{~mm}$ 厚さの中間材 （AZ31）を挿入して回収実験を行った。

図6に, $0.3 \mathrm{~mm}$ 厚さの AZ31板を挿入した時の接合界面の 組織写真を示す。この場合, 起爆側の界面 $(X=5 \mathrm{~mm})$ には 薄いチタンとマグネシウムの混合組織を形成し, 終端側に向 かうにつれて $(X=30,60 \mathrm{~mm})$ 混合組織はなくなる状況で あったが，全体にわたる両者の接合は良好であった。ここで みられた水平方向への組織の変化は, 一定厚さの爆薬を使用 したことによる。すなわち, 起爆側では水中衝撃波の減衰が 少なく強い圧力作用があるのに対して, 終端側では圧力が弱 まることに起因している。別の研究では, この種の圧力減衰 を改善する手法として, 爆薬の厚さを起爆側から遠ざかるに つれて次第に厚くすることを提案し, 実際に圧力の均一化を 実現できることが確認されている ${ }^{24)}$ 。

図6の一部で見られた接合界面の混合組織は, マグネシウ 
$5 \quad|||||||||||||||||||||||||||||||||||||||||||||||||||||||||||||||||||||||||||||||||||||||||||||||||||||||||||||||||||||||||||||||||||||||||||||||||||||||||||||||||||||||||||||||||||||||||||||||||||||||||||||||||||||||||||||||||||||||||||||||||||||||||||||||||||||||||||||||||||||||||||| \mid$

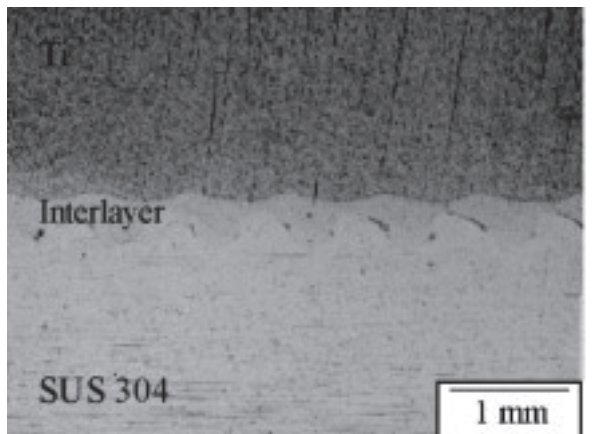

(a)

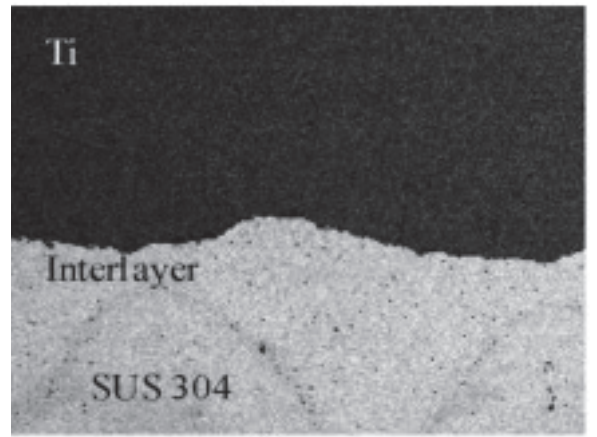

(c)

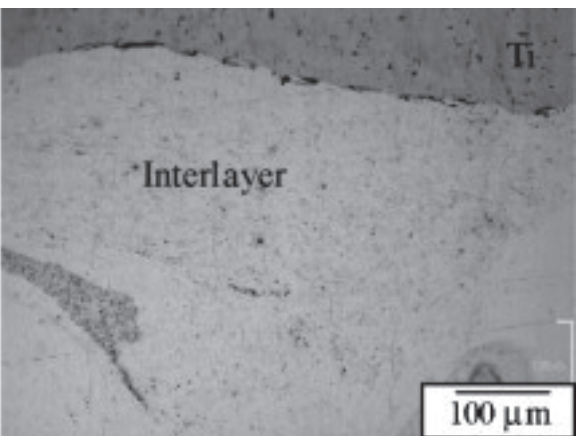

(b)

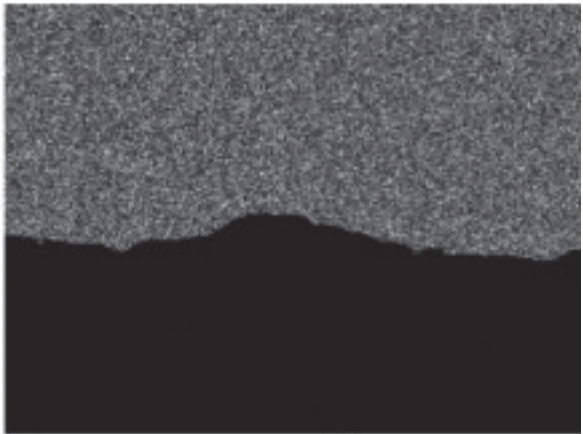

(d)

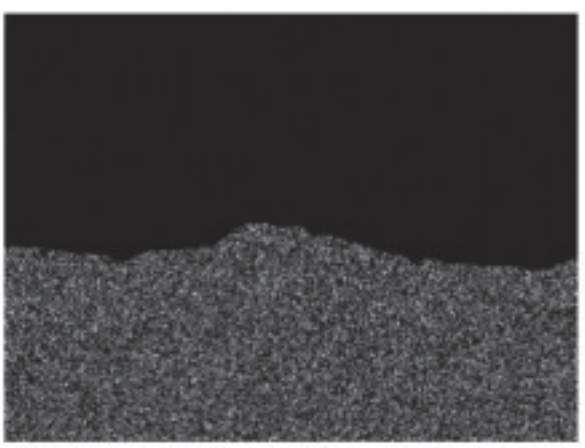

(e)

図 3 ステンレス鋼中間材を用いる方法で接合されたチタン/ステンレス鋼接合境界の微細組織 ${ }^{21}$ (a), (b) 光学顕微鏡組織, (c) SEM 像, (d) Ti分布, (e) Fe 分布

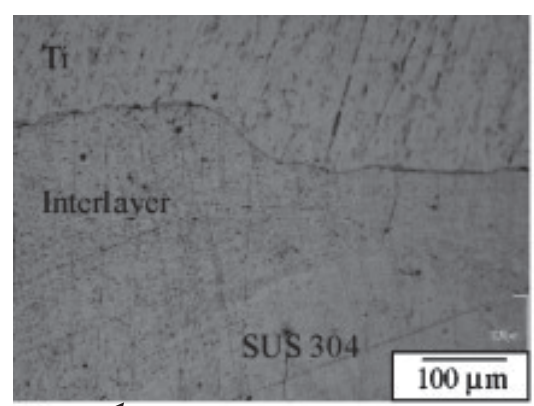

(a)

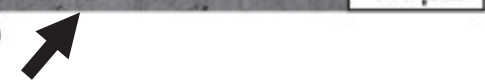

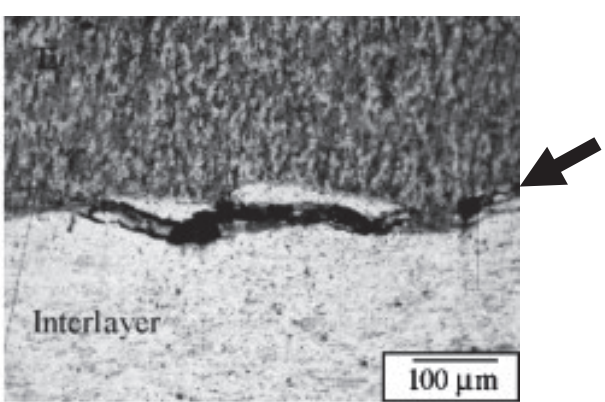

(b)

図4 動的試験結果 ${ }^{21)}$ （a）エネルギーを制御した場合，（b）エネルギー過剰の場合

ムに溶融が生じた後そこにチタンが溶け込んで生じたもの と思われた。幸いなことにこの合金系の場合には金属間化合 物を形成せず 2 相分離となるので，硬脆な境界層を生じない のが特徵である。境界層の硬度は 141〜 144 HV 程度（Ti；157 〜 $170 \mathrm{HV}, \mathrm{AZ31} ; 74-106 \mathrm{HV})^{23)}$ で, この層が両者の緩和層 として寄与することも期待できる。曲げ試験でも剥離するよ
うなこともなく，接合境界の良好な接合が確認されてい る ${ }^{23)}$ 。今回用いたのと同じ水中衝撃波を用いる方法で作製し たW-Cu接合体も，上記と同じく状態図が2相分離であり，同 様の 2 相混合組織が接合境界に生じる場合があることが確認 されている ${ }^{25)}$ 。 


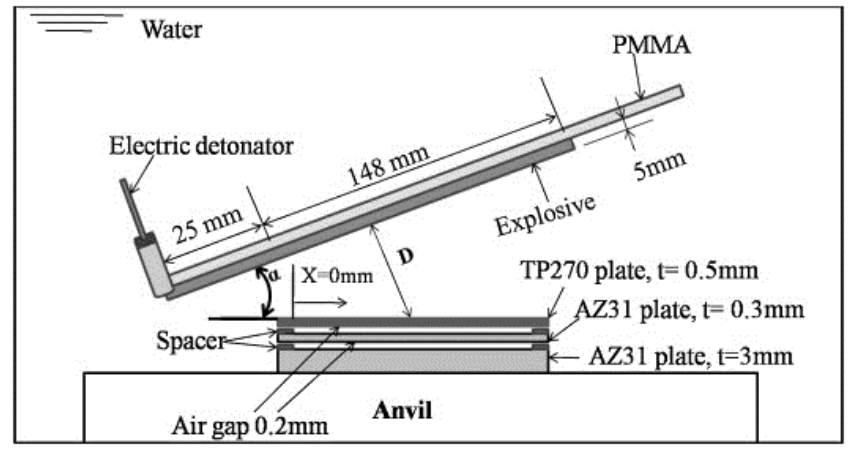

図 5 水中衝撃波を用いる爆発圧着法の模式図（中間材 を用いる場合) 23 )

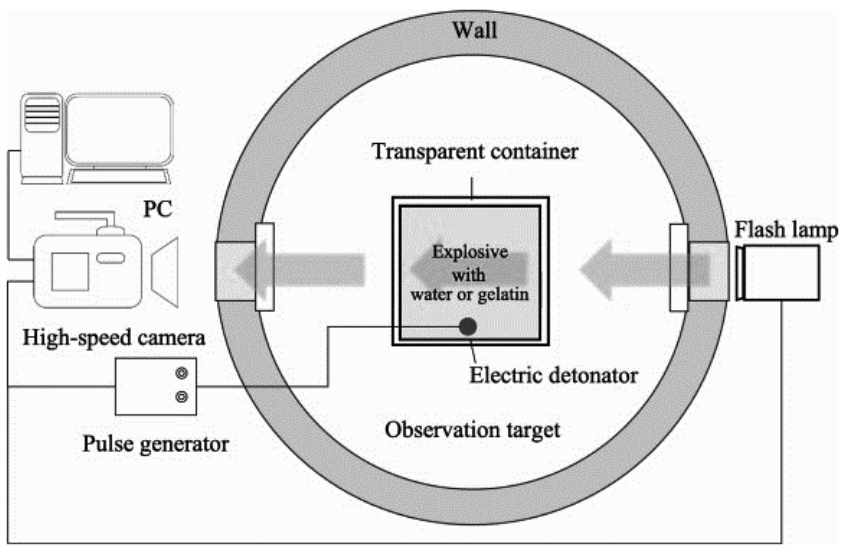

図7 媒質中を伝播する衝撃波の光学観察装置の模式図 ${ }^{29)}$

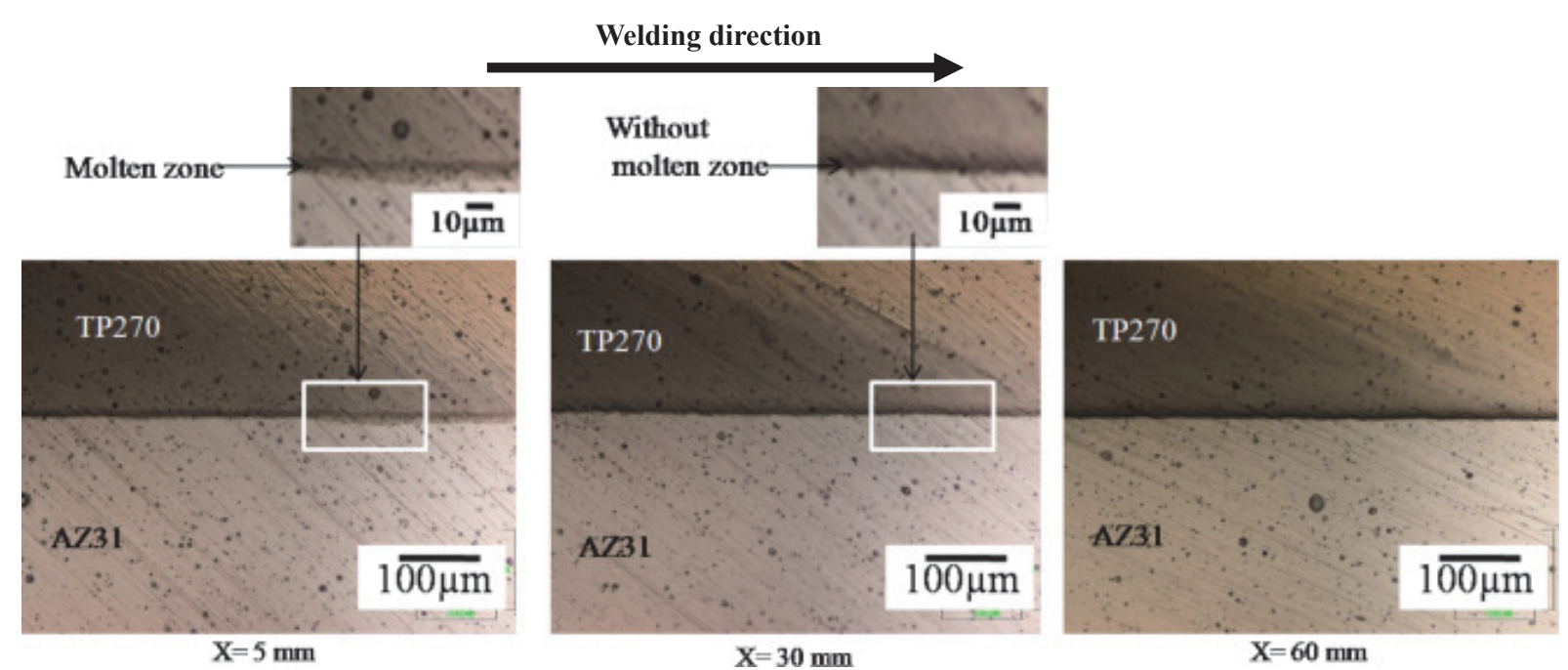

図6 光学顕微鏡を用いたチタン /AZ31 の接合界面組織 $\left(\alpha=20^{\circ}, \mathrm{D}=35 \mathrm{~mm}\right)^{23)}$

\section{3 各種の爆薬・媒質を利用する方法}

これまで使用する爆薬については詳しく紹介しなかった が,一般に爆発圧着には硝酸アンモニウムを主成分とする ANFO系の爆薬を利用することが多い。この爆薬は爆轟速度 が $2 \sim 3 \mathrm{~km} / \mathrm{s}$ 程度と比較的遅く, 衝撃波による材料の損傷を 抑制することができる。また，平行法を用いた場合でも前述 の水平方向への衝突点の移動速度が十分に遅いので，良好な 接合条件を比較的容易に実現できる。したがって，ANFO系 の爆薬で水中衝撃波による方法を利用できればよいが，この 爆薬は水溶性で，水を介する場合には確実な防水措置が必要 である。また，水の利用は種々の観点から施工上の制約が多 く, 代替の手法も検討が必要であると考えて, 水に代えてゼ ラチンを利用することの着想を得た。ゼラチンは生体組織中 の衝撃波の伝播を模擬することもあり ${ }^{26)}$ ，水と衝撃波特性が 比較的類似していることもかねてから知られていた ${ }^{27), 28)}$

まずは媒質中の衝撃波の伝播挙動を知ることが必要である ことから, 高速度カメラを利用した光学計測実験を実施し た。ここでは低爆速の ANFO系爆薬と高爆速の SEP爆薬を利 用して，水およびゼラチン中を伝播する衝撃波の挙動を観測 した。使用した光学系の模式図を図 $7^{29)} に$, 爆薬と媒体の設 置状況を図 $8^{29}$ に示す。図8の左はANFO系爆薬，右はSEP爆 薬を水もしくはゼラチンの上に配置し，右上端に設置した雷
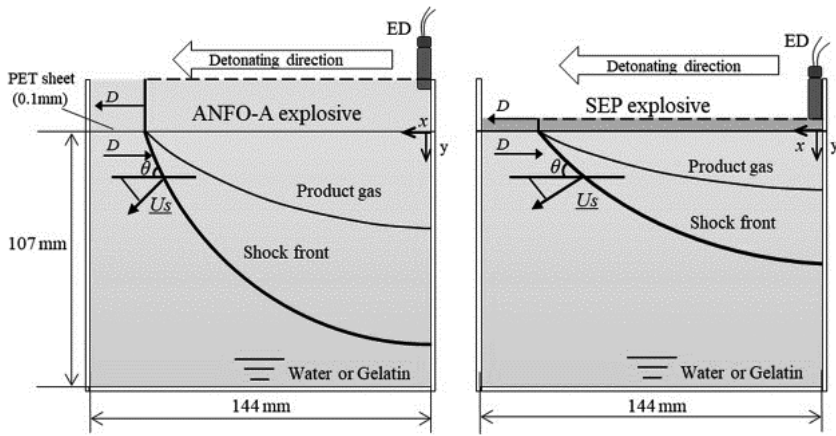

図8 ANFO系爆薬とSEP爆薬を用いた場合の水中およ びゼラチン中を伝播する衝撃波伝播観測装置の模 式図 ${ }^{29)}$

管で起爆した時に生じる衝撃波の伝播状況を模式的に示す。

光学観察結果を図 $9^{29)}$ に示す。図 $9(a)$, (b) はSEP爆薬の 水中とゼラチン中の衝撃波伝播挙動の光学観察結果であり, 図9(c) は両者の衝撃波面を重ねて示したものである。図9(e) 〜 (f) はANFO系爆薬について同様の結果を示す。光学観察 結果から明らかなように, 水とゼラチンを利用した場合の衝 撃波伝播挙動は 2 種類の爆薬を用いたいずれの場合もほぼ同 じで，水に関してこれまで得られている接合条件をそのまま 利用してゼラチンの実験を実施できることが確認された。現 


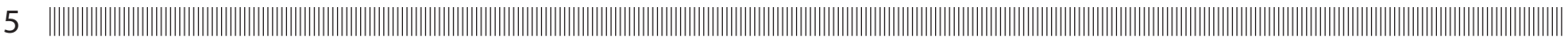

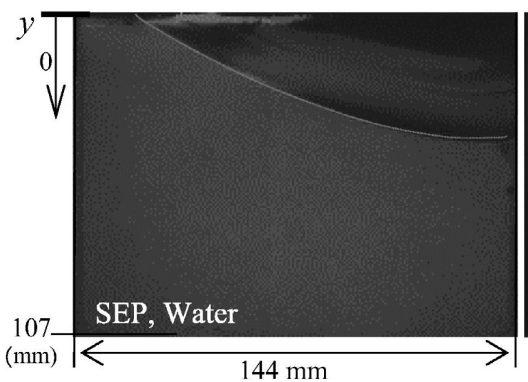

(a)

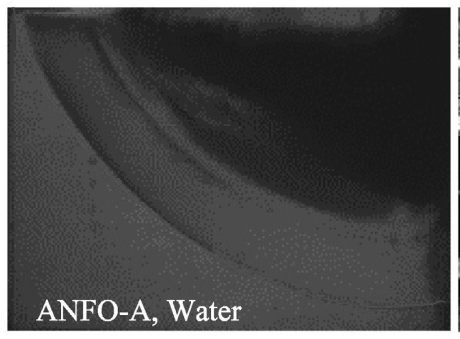

(d)

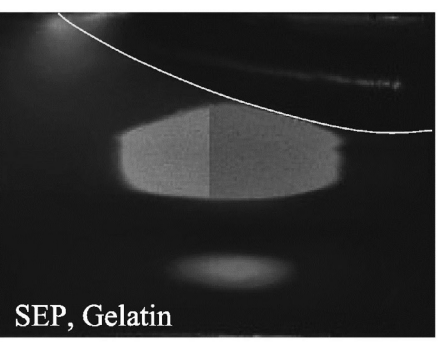

(b)

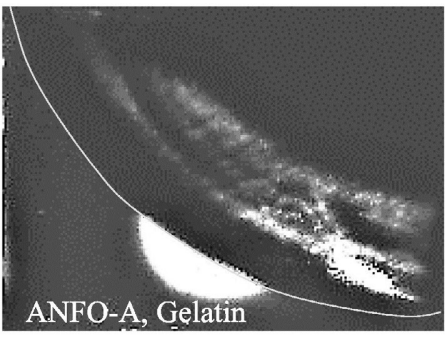

(e)

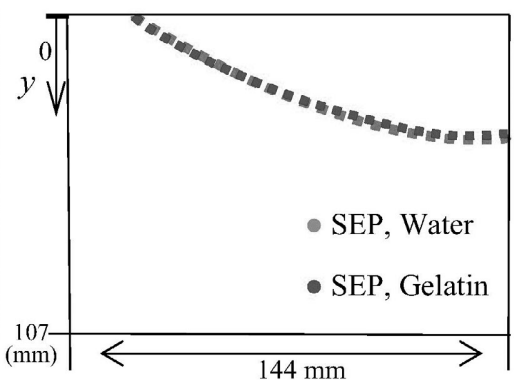

(c)

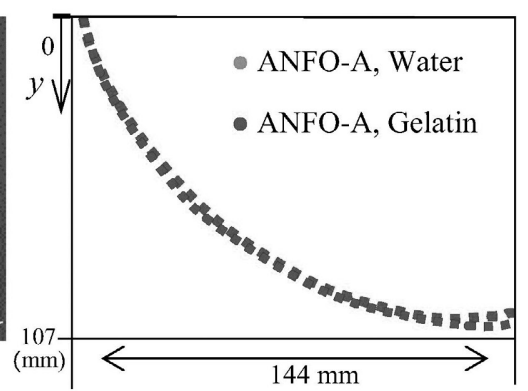

(f)

図9ANFO系爆薬とSEP爆薬を用いた場合の水中およびゼラチン中を伝播する衝撃波の光学観察結果 ${ }^{29)}$

在，このゼラチンを媒質として用いる方法による爆発圧着実 験を鋭意試みている ${ }^{30)}$ 。

\section{4. 各種応用の可能性}

本稿では工業的な応用事例についても紹介しておく。現 在, 最大で $4.2 \mathrm{~m} \times 7 \mathrm{~m}$ の大型のステンレスクラッド鋼が国内 で生産されており，異材の接合強度に高い信頼性が必要な継 手部材として広く使用されている。例えば，アルミニウム/中 間材/ステンレス鋼からなる極低温用管状継手，アルミニウ ム/鋼からなる構造用異材継手のほか, 導電用の異材継手 (ア ルミニウム/銅，アルミニウム/鋼）などが多く生産されてい る ${ }^{31)}$ 。また，マグネシウム合金の利用についても検討が進ん でいる2)。

通常の方法では難しい異種材料の接合には，本稿で紹介し た媒質を介する方法が有効であり，今後，軽金属に限らず， 多様な材料の組み合わせに対して広範囲に利用されることを 期待している。これまでの研究では, 水中衝撃波を利用して アルミニウムとジルコニアセラミック ${ }^{32)}$ の接合に成功して いるほか，工具鋼 ${ }^{33)} の$ 接合にも成果が上がっており，実験条 件を調整することで鋳鉄などの硬脆材に対しても接合が可能 ではないかと考えている。

水中衝撃波等を利用する方法の問題点は, 接合可能な面積 が限られることである。著者らは，大面積化に必要な技術で ある「金属薄板を重ねて爆発圧着する方法」についても検討 し，比較的良好な重ね爆着が可能であることを示している ${ }^{34)}$ 接合する板の厚さが板を重ねることで急変する部分の近傍で は，接合界面の波長が大きく変化したり，金属ジェットがト ラップされて生じた溶融組織が確認されたが，接合状態はお おむね均一で良好な接合を得ることが可能であった ${ }^{34)}$ 。

接合可能な材料形状に関しては，板の接合だけでなく棒や 管の接合も可能である。本稿の主題から少し外れるが，著者
らは最近，金属細管にろうを封入して束ねた多数管を大きな 金属管に詰めて周囲から爆薬で圧縮することで，均一に伸長 された多数穴構造を持つ多孔質材の創製を試みている。銅 ${ }^{35)}$ やアルミニウム ${ }^{36)}$ のほか, 複合素材からなる一方向多孔質 材 ${ }^{37)}$ も製造可能である。管に流体を流した時の圧力損失が小 さく, 伝熱特性にも優れており, 熱交換器等への応用を期待 している ${ }^{38)}$ 。

\section{5. 関連技術}

爆発圧着技術と関連の深い技術としては, 電磁圧接技術が 挙げられる。詳細は, 本連載講座 ${ }^{39)}$ や文献 ${ }^{40)}$ を参照していた だきたい。この方法によると接合境界に波状界面の形成が認 められることから, 爆発圧着と同様に高速傾斜衝突による金 属ジェットの形成と流体的挙動に基づく機構で接合している と思われ，主に軽金属の異材接合に対して高い接合強度を達 成できる。爆発圧着と異なる点は, 大容量コンデンサーに蓄 積したエネルギーを瞬間的に開放してコイルに沿って電磁加 速を行い, 線状もしくは点の接合が可能なことである。工場 内で異材接合を実施する場合には, この方法が有力な手法に なり得ると思われる。線状の接合は導爆線（ひも状の爆薬） の利用でも可能である ${ }^{1)}$ が, 安全の観点からすると, 爆発が 利用可能な特殊な施設か, 人のいない遠隔地での施工に限ら れる。

上記で紹介した点接合に関しては, 個人的には今後の技術 開発に関する新しい展開を期待している。局所領域（点）の 加速であれば, 多様な方法によって圧力作用を高めることは 可能で, 接合に十分な高速加速が達成できると思われ, 異材 の点接合を行う新しい装置の開発ができないかと考えてい る。かなり以前だが, SalamとAl-Hassaniは弾丸を水に衝突さ せて水の高速噴流を生じさせ, 点接合が実現可能なことを示

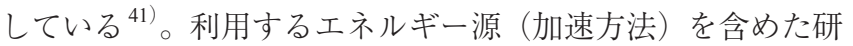


究の進展を期待したい。

また最近では，レーザーアブレーションによる加速を用い た点接合に関する研究報告 ${ }^{42)}$-45) も増えている。ただし現状 では，レーザーの均一性の問題や板を加速するためのエネル ギーが不足しているといった印象を持っている。

\section{6. おわりに}

ここでは軽金属の異材接合を中心に，爆発圧着技術の基礎 と接合性改善の手法や関連技術の可能性について紹介した。 軽金属は軽いので比較的加速されやすいものの，エネルギー が過剩になると，溶融や化合物が形成されて接合が妨げられ るので，エネルギー制御の観点での工夫が必要であった。本 稿では特に，中間材を利用する方法や，水中衝撃波などを利 用して薄板を加速する方法の有効性を紹介した。さらに，こ こで紹介した各種の高速材料加工技術が，広範に利用される ようになることを期待したい。

本稿では紹介できなかった技術としては，コールドスプ レーといった粉末の高速投射被覆技術 ${ }^{46)}$ のほか, 水中衝撃波 による超微細形状の打抜き ${ }^{47)}$ ・成形加工 ${ }^{48), 49)}$ など，いくつ か実現の可能性が高い技術も存在する。これらについても, 今後の新展開を期待している。

\section{謝 辞}

本稿の執筆にあたっては，旭化成株式会社の和田直之博士 から爆発圧着に関する最近の生産状況の情報を頂戴した。こ こに記して深謝申し上げる。

\section{参 考 文 献}

1) B. Crossland: Explosive Welding and Its Application, Oxford Univ. Press, (1982).

2) 花野嘉紀：溶接学会誌，87 (2018), 76-79.

3) 外本和幸：溶接学会誌, 87 (2018)，43-47.

4) 大塚誠彦：圧力技術, 53 (2015), 42-45.

5) 藤田昌大, 千葉 昂, 立川逸郎：日本金属学会会報, 20 (1981), 385-393.

6) M. Nishida, A. Chiba, Y. Morizono, M. Matsumoto, T. Murakami and A. Inoue: Mater. Trans., JIM, 36 (1995), 1338-1343.

7) P.K. Parchuri, S. Kotegawa, K. Ito, H. Yamamoto, A. Mori and K. Hokamoto: Mater. Des., 166 (2019), 107610.

8) I.A.Bataev, D.V.Lazurenko, S.Tanaka, K.Hokamoto, A.A.Bataev, Y.Guo and A.M.Jorge Jr.: Acta Mater., 135 (2017), 277-289.

9) I.A. Bataev, K. Hokamoto, H. Keno, A.A. Bataev, I.A. Balagansky and A.V. Vinogradov: Metals and Mater. Int., 21 (2015), 713-718.0

10) A. Mori, S. Tanaka and K. Hokamoto: Proceedings of SPIE - The International Society for Optical Engineering, (2017), 10328Q DOI: https://doi.org/10.1117/12.2270473

11) A. Kira, K. Hokamoto, Y. Ujimoto, S. Kai and M. Fujita: Int. J. Modern Phys. B, 22 (2008), 1653-1638.

12) X. Zeng, X. Li, X. Chen, X. Wang and H. Yan: Welding in the World, 63 (2019), 967-974.

13）西脇淳人, 熊井真次 : 溶接学会論文集, 34 (2016), 274-284

14) 熊井真次：溶接学会誌, 87 (2018), 48-56.

15) J. Feng, P. Chen, Q. Zhou, K. Dai, E. An and Y. Yuan: Int. J. of Multiphysics, 11 (2017), 315-325.

16) K. Hokamoto, T. Izuma and M. Fujita: Metall. Trans., 24A-19 (1993), 2289-2297.

17) R.H. Wittman: Proc. 2nd Symposium on Use of Explosive Energy in Manufacturing Metallic Materials of New Properties of Application thereof in the Chemical Industry, (1973), 153-168.

18) A.A. Deribas, V.A. Simonov and I.D. Zakcharenko: Proc. 5th Int. Conf. on High Rate Fabrication, (1975), 4.2.1-4.2.16.

19) I. Bataev, S. Tanaka, Q. Zhou, D.V. Lazurenko, A.M. Jorge Jr., A.A. Bataev, K. Hokamoto, A. Mori and P. Chen: Mater. Des., 169 (2019), 107649.

20) X. Chen, D. Inao, S. Tanaka, A. Mori, X. Li and K. Hokamoto: J. Manufacturing Processes, 58 (2020), 1318-1333.

21) P. Manikandan, K. Hokamoto, M. Fujita, K. Raghukandan and R. Tomoshige: J. Mater. Process. Technol., 195 (2008), 232-240.

22) S.H. Ghaderi, A. Mori and K. Hokamoto: Mater. Trans., 49 (2008), 1142-1147.

23) M.A. Habib, H. Keno, R. Uchida, A. Mori and K. Hokamoto: J. Mater. Process. Technol., 217 (2015), 310-316.

24) K. Hokamoto, K. Nakata, A. Mori, S. Tsuda, T. Tsumura and A. Inoue: J. Alloys Compd., 472 (2009), 507-511.

25) P. Manikandan, J.O. Lee, K. Mizumachi, A. Mori, K. Raghukandan and K. Hokamoto: J. Nucl. Mater., 418 (2011), 281-285.

26) 早川 理, 龍野 正, 高山和喜：医用電子と生体工学, 34 秋季 特別号，（1996），147

27) K. Nagayama, Y. Mori, Y. Motegi and M. Nakahara: Shock Waves., 15 (2006), 267-275.

28) C.J. Shepherd, G.J. Appleby-Thomas, P.J. Hazell and D.F. Allsop: AIP Conf. Proc., (2009), 1399-1402.

29) D. Inao, S. Tanaka, T. Yamashita and K. Hokamoto: Measurement: Journal of the International Measurement Confederation, 148 (2019), 106929.

30) D. Inao, A. Mori, S. Tanaka and K. Hokamoto: Metals, 10 (2020), 106.

31) https://www.asahi-kasei.co.jp/baclad/jp/index.html (2021年1月29日)

32) K. Hokamoto, M. Fujita, H. Shimokawa and H. Okugawa: J. Mater. Process. Technol., 85 (1999), 175-179.

33) W. Sun, X. Li, H. Yan and K. Hokamoto: J. Mater. Eng. \& Performance, 23-2 (2014), 421-428.

34) K. Hokamoto, A. Mori and M. Fujita: Int. J. Modern Phys. B, 22 (2008), 1647-1652.

35) K. Hokamoto, M. Vesenjak and Z. Ren: Materials Letters, 137 (2014), 323-327.

36) K. Hokamoto, K. Shimomiya, M. Nishi, L. Krstulović-opara, M. Vesenjak and Z. Ren: J. Mater. Process. Technol., 251 (2018), 262266

37) M. Nishi, S. Tanaka, M. Vesenjak, Z. Ren and K. Hokamoto: Metals, 10-2 (2020), 193.

38) Y. Sato, K. Yuki, Y. Abe, R. Kibushi, N. Unno, K. Hokamoto, S. Tanaka and T. Tomimura: International Heat Transfer Conference, (2018), 8189-8193.

39) 糸井貴臣：軽金属, 71 (2021)，掲載予定

40) 岡川啓悟：ぷらすとす, 1-4 (2018), 247-252.

41) S.A.L. Salam and S.T.S. Al-Hassani: Metallurgical Applications of Shock-Wave and High-Strain-Rate Phenomena, Dekker, (1986), 943959

42) X. Wang, C.X. Gu, Y.Y. Zheng, Z.B. Shen and H.X. Liu: Mater. Des., 56 (2014), 26-30.

43) S.Y. Yang and J.W. Bao: J. Mater. Eng. Perform., 27 (2018), 11771184.

44) X. Wang, F. Li, T. Huang, X.J. Wang and H.X. Liu: Opt. Lasers Eng., 115 (2019), 74-85.

45) F. Li, X. Wang, X. Wang and H. Liu: J. Mater. Eng. Perform., 29 (2020), 1336-1345.

46) V.K. Champagne: The Cold Spray Materials Deposition Process, Fundamentals and Applications, Woodhead, (2007).

47) S. Tanaka, I. Bataev, M. Nishi, I. Balagansky and K. Hokamoto: Int. J. Mach. Tools Manuf., 147 (2019), 103457.

48) S. Tanaka, K. Hasegawa, I. Bataev, A. Kubota and K. Hokamoto: Mater. Des., 198 (2021), 109341.

49) S. Tanaka, D. Inao, I. Bataev, A. Kubota and K. Hokamoto: Manuf. Lett., 27 (2021), 8-12. 